\title{
IMPACT OF REPUTATIONAL LOSS ON FINANCIAL PERFORMANCE OF THE BANK
}

\author{
Daiva JUREVIČIENĖ(D ${ }^{1 *}$, Ksenija KRAVEC ${ }^{2}$ \\ 1, 2 Department of Economics Engineering, Faculty of Business Management, \\ Vilnius Gediminas Technical University, Sauletekio al. 11, 10223, Vilnius, Lithuania \\ ${ }^{*}$ E-mail: daiva.jureviciene@vgtu.lt
}

\begin{abstract}
Purpose - the purpose of the article is to identify the criteria influencing on the reputational performance of a financial organisation and recognise the impact of reputation on the activities of a financial institution.

Research methodology - to estimate the reputational impact on a financial organisation an interview with experts was conducted. In order to process the received data SAW, COPRAS and geometric mean methods were used. The mentioned methods were applied for performance measurement to ensure the inclusion of the reputation-sensitive data.

Findings - the weakest position of the financial company in terms of reputational condition implies decreased efficiency of its performance. The degree of reputation and the impact of repercussions on the organisation's performance can be further measured through financial analysis.

Research limitations - the financial organisation analysed in the current study does not provide services for local clients, hence there is no possibility to obtain primary data from direct interactors.

Practical implications - the research results provide insight towards key areas to look on while conducting root-cause analysis for decrease of financial performance; reputational impact measurement model can be used for further planning processes related to the future repercussions prevention.

Originality/Value - literature overview results prove that it is still argued over the way reputational impact could be measured due to the fact that organizational reputation is attributed to a long-term intangible asset which is sensitive towards the subjectivity of the analysed matter. While it is usual to measure the reputation from the clients' perspective, the research on reputation impact relies on the particular statistical data on company's condition in the market.
\end{abstract}

Keywords: organisation, bank, reputation, risk, management, financial results.

JEL Classification: C81, C83, G21, G32, G41, L14.

Conference topic: Contemporary Issues in Economics Engineering.

\section{Introduction}

Successful management of an organisation's reputation is directly related to the implementation of appropriate risk management. An unfavourable state of reputation can negatively affect the organisation's credibility and increase the negatively associated interest of the public. Wrong risk management and ignoring the risks is often a consequence of reputation loss. With regard to financial services of organisations and banks, the risk implies possible losses resulting from interactions with uncertainty. The adverse reaction of counterparties, shareholders, investors, debtors, market analysts, regulators and other related parties to the bank's behaviour in the market may negatively affect the bank's ability to maintain existing business relationships and access to financing sources. Appropriate and precise risk measurement is crucial in order to lead an organisation with compliance to its strategies. The aim of the article is to identify the impact of reputation on bank's financial performance. To achieve this goal, the following tasks are implemented: (1) systematising the theoretical concepts of reputation, reputation risk and its impact assessment; (2) developing a methodology for assessing the impact of the loss of reputation on financial organisation performance; (3) performing a multi-criteria analysis on the reputation factors. Research methods used: analysis and synthesis of scientific literature: systematisation, comparison, summarising; multi-criteria valuation methods: SAW, COPRAS, geometric mean. 


\section{The relationship between organisational reputation and operational risks}

According to Basel II, operational risk is defined as the risk of loss resulting from inadequate or failed internal processes, people and systems, or from external events. This definition includes legal risk, but excludes strategic and reputational risk (Basel Committee on Banking Supervision, 2006). Over the last few decades, the risk regulation of financial institutions has evolved (Basel Committee on Banking Supervision, 2003, 2006, 2009) and has included reputational risk within operational risk. The reputational loss is often a consequence of the risk management process. Reputation risk, according to Barakat, Ashby, Fenn, and Bryce (2019), is classified as an operational risk. In order to analyse properly the impact of reputational risk on the activities of a financial company, it is particularly important to understand the concept of risk, its type and management peculiarities. Comparative analysis of various authors' scientific works (Bergh, Ketchen, Boyd, \& Bergh, 2010; Xu, Zheng, Wang, Ji, \& Wang, 2019) can be used to analyse the concept of risk in a broad sense and to identify the main elements of risk concept.

As the importance of understanding the risk management is becoming more paramount, the organisations offering financial services increasingly associate risk management not only with additional activities, but also with significant competence that can be used as the main tool for gaining competitive advantage. According to Černikovaite (2018), the globalisation of financial services creates complex conditions for financial organisations' activities and successful bypass of various loss types. Due to changes in business environment, operational risk becomes more tangible and noticeable. Enterprise solvency, customers' assessment, financial fraud occurrence can be heavily affected by the operational risks existing across organisations. The specific and individual definition of operational risk in each company is particularly important (Tuan, 2016). The definition of operational risk has to be based on the nature of activity and external environment. Operational risk can be identified as a risk of a loss due to inadequate internal control processes, employee errors, unlawful actions, malfunctions of information systems, external events. Daily operational process disruptions are also considered to be the source of operational risk losses. According to Bergh et al. (2010), the classification of operational risk is based on the distribution of external and internal risk factors. Internal operational risk in the organisation arises in the process of implementing the company's strategy. Internal operational risk sources are people, processes, and technologies. Meanwhile, external operational risk occurs due to factors, such as political, tax, regulatory, government decisions, social, competitive and other factors. According to Yang, Hsu, Sarker, and Lee (2017), operational risk is usually related to a variety of relationships, processes and technologies. External factors also lead to operational risk. Risks related to external factors are identified as the risk of loss due to damaged assets of the organisation, operating restrictions, competitive environment, and regulatory rules. Bromiley, McShane, Nair, and Rustambekov (2015) emphasise that reputational risk is multifaceted and reflects the perception of other market participants. The analysis of the impact of potential repercussions of reputational risk is inseparable from the deep understanding of the reputation concept and the evaluation of the concept.

\subsection{Reputational significance at the level of organisation}

Further development of performance and reputation strategies is always accompanied by risk. The significance of reputation risk is often underestimated in terms of scale and influence. Existing and emerging risks imply not only adverse consequences for the organisation, but also opportunities. The reduction of potential threats risk and increase of organisational capabilities can be reached by prudent and strategic reputation model (Braga, Niemann, \& Hellingrath, 2018). Critical situations are a natural phenomenon of business conduct; therefore, proper preparation for such potential conditions is necessary to minimise the loss of reputation. Reputational risk arises from self-contained actions of the organisation and the expectations of stakeholders. Reputational risk can be detrimental not only to the ability of the organisation to function, but also to community-based authority (Carroll Craig, 2015). Organisational managers usually perceive reputational risk only as a threat of potential loss. Carroll Craig (2015) explains this by the fact that reputation risk is the sum of potential profits and losses of reputable capital. According to Nguyen and LeBlanc (2018), the effects of reputational risk can be measured by the emergence of crises or problems. Crises usually occur due to lower degree of profitability, a slowdown in organisational processes, uncertainty in decision-making, and urgency. The problem is treated as the difference between the expectations of the individuals involved in the organisation and the current perception of the organisation's behaviour and reaction. Generally, critical situations are unexpected and open to different types of speculative interpretations, while huge problems arise slowly and predictably, and are determined by the priority given by the people involved. In practice, critical situations force organisations to make sudden decisions and drastic changes while gradually emerging problems allow organisations to deepen the analysis of the problem sources and develop consistent learning through effective solutions. Accordingly, the emergence of a different type of exposure determines the individual model of the organisation's reputation risk management and the exceptional controls that guarantee future protection against re-emergence.

The impact of risk is directly related to a specific event and to the organisation's ability to respond appropriately and solve problems. Reputation risk criteria are formed by the factors of capital, financial, operational, social and intangible risks (Nguyen \& LeBlanc, 2018). Reputational risk elements can be divided into social and political, commercial and organisational (Hedgecoe, 2016). Social and political elements relate to external standards of public behaviour, i.e. with environmental standards, labour relations, and indifference towards employees, discrimination, 
violation of human rights, inadequate reaction, corruption, and bribery. The elements of commercial and organisational activities are of internal origin, namely, the interruption of services, poor quality consulting, fraud, inefficient management, and intervention by regulators, defending counterparties, internal conflicts between members of the organisation, safety issues, and strategic decisions. When a repute problem arises, it is difficult to measure the loss properly, as reputation is attributed to intangible assets. However, in order to measure the impact of reputation on the organisation's activities, Maden, Arıkan, Telci, and Kantur (2012) propose to evaluate such sources of risk as financial indicators, company management, changes in employee and organisational culture, marketing strategy, compliance with laws, quality of services, internal risk management system and controls, success of implementation.

The importance of the organisational reputation itself has increased over the decade, as the unsuccessful results and the accumulated experience of the examples have made it possible to understand the obvious value of reputation in the context of an organisation. According to Matuleviciene and Stravinskiene (2015), one of the most important objects for analysis is the heterogeneity of the organisation's reputation. Heterogeneity in the context of reputation evaluation means differences or uniformity of dimensions of perception of the reputation of the stakeholder organisation. It is important to define that the reputation of each organisation must be individual and tailored to the relevant criteria. Each stakeholder perceives the assessment of an organisation and its operational processes differently; respectively, the organisational reputation from each perspective may vary. It is obvious that in practice, one general reputation assessment is not possible. Reputation is based on the clear knowledge of the situation, therefore, the reputation perception, usually, can only be either positive or negative.

Maden et al. (2012) note that reputation is the link between many elements, i.e. employees' opinion about the workplace, consumers' attitude towards service provider, return on the acquisition of the investors' shares. Accordingly, reputation management is planned to take into account the purpose and orientation of the organisation, which determines the individuality of the reputational risk management model and its inconsistency with the views of certain stakeholder groups. The reputation of the organisation as a social identity is widely used in the organisation's positioning strategy, as it has a significant impact on the choice of user products and services (Nguyen \& LeBlanc, 2018). In addition, a well-established reputation of the company helps to attract potential investors and skilled workers and contributes to the development and maintenance of customer loyalty. Finally, the reputation of the company has a significant impact on the competitiveness of the organisation in the market, so analysing the influence of reputation and its risks is particularly important for each organisation seeking to maintain its competitive edge. In the context of the service organisation management, appropriate service delivery and sales system is considered to be the foundation of the organisation that maintains and enhances the reputation level.

The concept of reputation conceptualisation describes the impact of past actions of an organisation on its stakeholders (Černikovaite, 2018). This kind of influence is determined by the beliefs of the stakeholders about the behaviour of the organisation in relation to the behaviour of its competitors. Therefore, companies that have a positive reputation can successfully influence stakeholders' decision-making processes. Good reputation, for example, reflects the quality and reliability of the company's products or services and therefore has a positive impact on customer behaviour, satisfaction, loyalty. As González Sánchez and Morales de Vega (2018) state, in the labour market, a high level of corporate reputation can help attract and retain talented individuals, reduce employee turnover and increase performance by lowering wages, based on increased employee motivation. In addition, negotiation, contracting and monitoring costs in supplier markets can be reduced if the company has a good reputation. Opportunities for a reputable organisation to gain access to larger capital markets are increasing, as investors tend to believe that such reputable companies are reliable and valuable in terms of credit. Thus, a good reputation attracts investors and can allow the company to choose higher emission prices.

In terms of public reputation perception, the level of reputation depends on the opinion of various stakeholder groups (Lange, Lee, \& Dai, 2011). As mentioned earlier, since these opinions are not necessarily harmonised, a company may have a "variety of reputation". These diverse reputations form the company's overall reputation and broad public perception, which is influenced by each individual's self-interest and needs, playing an important role in shaping this overall reputation profile. Therefore, the reputation indicator may be measured by the perception of a public reputation for many of the above-mentioned behavioural results, as the public is made up of potential customers, employees, shareholders, and competitors.

\subsection{Reputation assessment opportunities}

Carroll Craig (2015) imposed that reputation of companies can be assessed relying on four groups of categories - (1) value, (2) leadership, (3) management, (4) responsibility. Analysis of value generated profit, and position in the market, acts as evaluation of financial performance indicators. Approach to leadership combines conclusions about organisational vision, leadership and strategic decisions. The definition of the management criterion for reputation is based on the transparency of management procedures, relationships with stakeholders and customers.

The organisation's investments and ideas for the well-being of employees, society and the environment ensure a positive assessment of the responsibility criterion. The condition of an organisation's reputation can be assessed on the basis of the reputation dimensions. Conclusions on the stakeholders' behavioural and decisive factors by Fombrun, Ponzi, and Newburry (2015) prove that the reputation factors could be divided into the following 6 dimensions: 
1. Financial performance dimension: profitability, organisational investment risk, competitiveness, growth prospects;

2. Vision and leadership dimension: future vision, governance, market opportunities;

3. The dimension of goods and services: progress, quality, the value of money, goods and services, innovation;

4. The dimension of the working environment: good working conditions, good workers, a fair system of remuneration for employees;

5. Social responsibility dimension: governance, attractive employer status, good employee network;

6. The dimension of emotional attraction: positive emotions in relation to the organisation, admiration, trust in organisation and respect.

Table 1. Breakdown of organisational reputation evaluation dimensions (source: prepared by the authors according to De Luca (2017), Petrokaitė \& Stravinskienė (2014))

\begin{tabular}{|l|l|}
\hline \multicolumn{1}{|c|}{ Indicators } & \multicolumn{1}{|c|}{ Dimensions } \\
\hline $\begin{array}{l}\text { Business results, profitability, competitiveness, growth, the threat of } \\
\text { bankruptcy, the degree of inadequacy }\end{array}$ & Good financial performance \\
\hline $\begin{array}{l}\text { Organisational past and future actions, clear vision, clear short and long-term } \\
\text { strategies }\end{array}$ & Business strategy \\
\hline $\begin{array}{l}\text { Ability to adapt to change, risk management, coordination, flexibility and } \\
\text { communication with the external environment }\end{array}$ & $\begin{array}{l}\text { Business strategy } \\
\text { implementation }\end{array}$ \\
\hline Market leadership, recognition, development & Leadership \\
\hline $\begin{array}{l}\text { Good quality of goods and services, implementation of quality management } \\
\text { systems, innovation, value creation, orientation towards consumers }\end{array}$ & Organisational products \\
\hline Focus on consumers, listening to offers, effective advertising & Customer focus \\
\hline $\begin{array}{l}\text { Installation of product and service development programs, investment in } \\
\text { research and development, new and unusual distribution channels }\end{array}$ & Innovation and value \\
\hline $\begin{array}{l}\text { Teamwork and openness to change, environmental credibility, respect for the } \\
\text { culture promoted by the organisation }\end{array}$ & Organisational culture \\
\hline $\begin{array}{l}\text { Ability to attract and retain talented employees and nurture them; good } \\
\text { working conditions, employee satisfaction and motivation. }\end{array}$ & Human resources \\
\hline $\begin{array}{l}\text { Honesty, transparency, avoidance of aphorisms, corruption and fraud, } \\
\text { promotion of ethical behaviour of employees }\end{array}$ & Fair and ethical activity \\
\hline
\end{tabular}

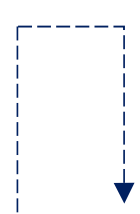

Identification of reputational loss impact

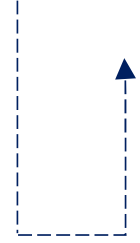

Table 1 reflects the essence of the key dimensions of corporate reputation assessment - indicator groups are based on financial values of results, vision and leadership, goods and services, the work environment, social responsibility and emotional attractiveness that create a common reputation. Every profit-making organisation, first, focuses on its performance and effectiveness, so most of the standard business units understand the repercussions of their reputation only if they notice the result through the prism of financial achievement or loss. However, to obtain a deep insight into the core of the nature of financial profit or loss it is favourable to analyse the organisation's activity by evaluating its condition in each of the dimensions.

According to a number of authors, evaluating the attributes related to the organisational reputation overlaps there is a set of six elements in the literature, which forms the model of the reputation index (Fombrun, Ponzi, \& Newburry, 2015; Lange et al., 2011, etc). The model includes such criteria as emotional attractiveness, work environment and employer image, vision and leadership, social responsibility, financial results, products and services. Authors believe that proper management of these criteria can ensure business success. However, it can be noted that Nguyen and LeBlanc (2018) suggest understanding the influence of reputation through dynamism, time, bilateralism of the relationship, and the ranking of the organisation in view of its competitors, the diversity of the organisation's reputation, based on the organisations economic, social and personal background. It may be concluded that the organisation's reputation is the public's comprehensive assessment of the organisation over time.

By systematising the opinions of the authors on the significance of reputation, it can be outlined that there is greater support in the literature for the approach based on the expectations of both external and internal participants, which motivates the appearance of reputation factors and, consequently, their instant assessment. It can be noted that according to Lange et al. (2011), reputation can be perceived differently depending on the way the external parties join the group, however, the formation of individual opinion is usually determined by the attitudes of other external events and parties. Therefore, in practice, reputation assessment based simply on an approach existing solely on an individual basis is not possible.

\section{Research methodology}

In order to complete the analysis of the performance considering the influence of both external and internal reputational image factors, the interview with the experts inside the company is conducted to obtain the before mentioned factors; then the factors data is systemized and reflected in terms of the analysed financial company. After the systemized data 
is ready, the experts evaluate the importance levels. To identify the year of the bank's activity, which was most affected by the decrease of reputation the multi-criteria analyses is being executed - at this point, the qualitative data is transposed with the quantitative. The selection of inside company experts for the interview has been executed relying on such criteria: experience in risk management activities and customer relationship, knowledge in the financial organisation operations, workplace in the analysed bank, project work related to the valuation of bank's financial/reputational performance (Table 2).

Table 2. Interview participation requirements and metrics of the respondents elected (source: prepared by authors)

\begin{tabular}{|c|c|c|c|}
\hline Criteria & Applicant I & Applicant II & Applicant III \\
\hline Risk Management experience & $3.5 \mathrm{yrs}$ & $4 \mathrm{yrs}$ & Yes \\
\hline $\begin{array}{c}\text { Customer service delivery } \\
\text { experience/interaction }\end{array}$ & Yes & Yes & Yes \\
\hline $\begin{array}{c}\text { Daily work related to financial } \\
\text { operations }\end{array}$ & $\begin{array}{c}\text { Custody Back Office } \\
\text { Team Lead }\end{array}$ & $\begin{array}{c}\text { Corporate Actions and } \\
\text { Income Team Lead }\end{array}$ & $\begin{array}{c}\text { SME (subject matter expert) } \\
\text { within International } \\
\text { Settlements }\end{array}$ \\
\hline $\begin{array}{c}\text { Position within the bank } \\
\text { Risk prevention/management related } \\
\text { project }\end{array}$ & $\begin{array}{c}\text { Payable TAX automated } \\
\text { system implementation }\end{array}$ & $\begin{array}{c}\text { Loss Case Analysis: } \\
\text { Planning Cross-border } \\
\text { trades }\end{array}$ & $\begin{array}{c}\text { Free Risk Assesment } \\
\text { Matrix creation within } \\
\text { Settlement Processes }\end{array}$ \\
\hline $\begin{array}{c}\text { Internal risk assessment docu- } \\
\text { mentation preparation (RIA filling) }\end{array}$ & Yes & Yes & Yes \\
\hline
\end{tabular}

There were three respondents selected - two of them are leading persons within the team and one of them takes up the position of the risk management operations officer in the analysed bank. To identify the influencing factors, the informal interview has been executed due to the fact that using this type of interview, the freedom granted gives the researcher the opportunity to gather informative knowledge and data in a convenient way (Miles, Huberman, \& Saldana, 2018; Yazdani, Alidoosti, \& Zavadskas, 2015). Yazdani et al. (2015) suggest using the multi-criteria methods due to the easiness to quantify the complex phenomena reason.

Table 3. Multi-criteria analysis process: equations used (source: Ginevičius \& Podvezko, 2008; Yazdani, Alidoosti, \& Zavadskas, 2015)

\begin{tabular}{|c|c|c|c|}
\hline (1) & $\begin{array}{l}\text { SAW method. The sum of all normalized values for } \\
\text { all indicators for each object is calculated. The } \\
\text { normalization of the data is followed by this formula } \\
\text { SAW method. The best value of the criterion } S_{j} \\
\text { when it is the highest. It can be assumed that the } \\
\text { weights of all indicators are the same. However, in } \\
\text { practice, a variety of weighting methods are often } \\
\text { based on experts opinion. }\end{array}$ & $\tilde{r}_{i j}=\frac{r_{i j}}{\sum_{i=1}^{m} r_{i j}}$ & $\begin{array}{l}\text { Here the } r_{i j} \text { stands for the } \\
\text { value of the } \mathrm{i}^{\text {th }} \text { index for the } \\
\mathrm{j}^{\text {th }} \text { object. } \\
\text { Here } w_{i}-\text { weight of the } \mathrm{i} \text {-th } \\
\text { indicator; } \tilde{\boldsymbol{r}}_{i j}-\text { normalized } \\
\text { value of ith index for jth } \\
\text { object. }\end{array}$ \\
\hline (3) & $\begin{array}{l}\text { If more than two experts gave their opinions, the } \\
\text { level of compatibility of the expert group is } \\
\text { determined by calculating the Kendall concordance } \\
\text { factor W. }\end{array}$ & $\begin{array}{c}E=\left\|e_{j j}\right\| \\
(i=1, \ldots, m ; j=1, \ldots, r)\end{array}$ & $\begin{array}{l}\text { Here } m \text { is the number of } \\
\text { comparable items (objects), } r \\
\text { is the number of experts. }\end{array}$ \\
\hline (4) & $\begin{array}{l}\text { The geometric mean of the normalized values of all } \\
\text { indicators which can be calculated relying on the } 1 \text { st } \\
\tilde{\boldsymbol{r}}_{i j} \text { formula. The priority sequence of objects defined } \\
\text { by the formula does not depend on the weight of the } \\
\text { indicators, therefore, this size is not included in the } \\
\text { formula. The best value for criterion } \Pi \mathrm{j} \text { is the } \\
\text { highest. }\end{array}$ & $\int_{i=1}^{m} \tilde{r}_{i j}$ & $\begin{array}{l}\text { Here } \tilde{r}_{i j} \text { is the normalized } \\
\text { value of the ith index for the } \\
\mathrm{j}^{\text {th }} \text { object. }\end{array}$ \\
\hline (5) & $\begin{array}{l}\text { COPRAS method. Calculation of normalized indices } \\
\text { sum for each element } \mathrm{j} \text {. The alternatives are } \\
\text { described in both the reducing indexes } S_{-j} \text { and the } \\
\text { increasing indexes } S_{+j} \text {. }\end{array}$ & $\begin{array}{c}S_{+j}=\sum_{i=1}^{m} d_{+i j} \\
S_{-j}=\sum_{\substack{i=1 \\
i=\overline{1, m} ; j=\overline{1, n}}}^{d_{-i j}}\end{array}$ & $\begin{array}{l}\text { Here } d_{i j} \text { is the sum of non- } \\
\text { subjective obtained values }\end{array}$ \\
\hline (6) & $\begin{array}{l}\text { COPRAS method. The relative significance } Q_{j} \text { of } \\
\text { each alternative } a_{j} \text { calculation. Based on the } \\
\text { calculated relative } Q_{j} \text { values, the priorities of the } \\
\text { alternatives are determined. The higher value of } Q_{j} \text {, } \\
\text { the higher is the priority of the alternative. }\end{array}$ & 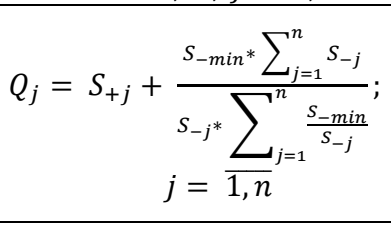 & $\begin{array}{l}\text { The resulting significance of } \\
\text { the alternative } \mathrm{a}_{\mathrm{j}} \text { in } \mathrm{Q}_{\mathrm{j}} \text { shows } \\
\text { how much the chosen } \\
\text { alternative corresponds to } \\
\text { the pattern of the variation of } \\
\text { the reputation size. }\end{array}$ \\
\hline
\end{tabular}


The SAW method is one of the best known, most commonly used multi-criteria assessment methods. The methods calculated $S_{j}$ criteria accurately expresses the idea of quantitative multi-criteria methods by combining values of indicators and their weights into one size. The experts are asked to evaluate the value of the indicator from 0.01 to 1 , the sum of the weights of the expected values should not exceed 1. Another method to include is the geometric mean of the normalized values of all indicators where there is no relation on the adjusted weights (Azar \& Mostafaee Dolatabad, 2019). COPRAS method is a multi-criteria assessment in a complex proportional way, which distinguishes among other multi-criteria assessment methods for important properties that allow a more accurate estimation of calculation results (Table 3).

\section{The effect of reputation on the bank's financial performance}

Based on the structured theoretical concepts related to the reputational consideration, it can be said that the level of organisational reputation may depend on both internal and external factors. Each of the listed factor groups can also be attributed to the results of the financial performance, strategy implementation, and quality of services, working environment, social responsibility and emotional experience. Indicators, such as employees' number, generated loss or operating expenses, labour productivity, can characterise internal reputational factors. Meanwhile, external factors affecting the reputation levels can be explained by the involved parties' reaction on the organisation's activity combined with the outlook on the market and economic events. The empirical study includes interview data, which gives an opportunity to identify the way the reputational impact could be measured. The results concluded during the informal interview with three experts within the financial banking services in the analysed bank reflect the possibility to evaluate the impact of reputation through market ratings. While evaluating the reputational impact of the analysed bank, it was proposed by the interviewers to rely on such widely known and usable ratings as Brand Finance Global Banking (1), Global 100 Most Sustainable Corporations (2), Most Valuable Nordic Brands Top 50 (3), Green Ranking Global Top 100 (4), Moody's Ratings (5). To identify the year when the bank's results were mostly affected by reputational factors, the mentioned ratings are included in the multi-criteria study. From the list of theoretical reputation factors proposed by scientific studies, during the informal interview with the experts, it was approved to include such factors as the level of organisation expenses (1), number of employees in the analysed bank and its competitors (2), social responsibility indexes: environmental, social and governance (3). The decision to involve the reputational factors into the further study was taken only when all three experts approved that importance in the reputational context is valid. Therefore, in order to evaluate the year that is mostly affected by the reputational factors, multi-criteria assessment models include the following elements: (1) Ratings: Brand Finance Global Banking 500 (100). (2) Ratings: Global 100 Most Sustainable Corporations. (3) Ratings: Most Valuable Nordic Brands Top 50. (4) Ratings: Green Ranking Global Top 100 (Nordics). (5) Development in the number of job ads over time in Denmark. (6) Social responsibility: Environment. (7) Social responsibility: Social. (8) Social responsibility: Governance. (9) Income statement. Operating expenses, DKK, (10) Number of employees: analysed bank. (11) The number of employees: competitor bank I. (12) Number of employees: competitor bank II. (13) Moody's rating: Issuer Outlook (positive/negative). (14) Moody's rating: Class History - Counterparty Risk Assessment. (15) Moody's rating: Issuer Rating, (16) Moody's rating: Commercial Paper. (17) Moody's rating: Short Term value. (18) Moody's rating: Baseline Credit Assessment. (19) Moody's rating: Bank Deposits Frequency. The multi-criteria assessment has been conducted relying on three methods: SAW, COPRAS and geometric mode. While implementing SAW and COPRAS methods, there were two scenarios applied - one scenario has an assumption that the importance weights of the factors are equal while the second one carries the assumption that the importance weights, which were chosen by interviewers, and which do have the valid and realistic meaning in terms of reputation impact identification.

The systemised and concluded results given by each of the methods used is placed in Table 4. Conducting the multi-criteria relying on the SAW method the mostly affected year is chosen by the measured $S_{j}$ coefficient. At first, it was decided to evaluate the reputation impact on the specific year activity assuming that all of the criteria are equally important. This means that each of the criteria had a weight of 0,053 or $1 / 19$ as the overall number of criteria reaches the level of 19 (7). While applying the equal weight assumption in SAW method completion, the measured $S_{j}$ coefficient was the lowest in $2015 \mathbf{- 0 . 1 9 0 8}$, which means that this year's activity of the company was the least affected by the reputation criteria. The largest $S_{j}$ coefficient measure is fixed at the 2018 year's activity assessment point - the level reaches the value of $\mathbf{0 . 2 2 4 3}$ which implies that the position of the company in 2018 was significantly affected by the reputational risk events.

The SAW method is also applied including the factors, the importance of which is assessed by experts. When evaluating the multi-criteria methods, it is necessary to emphasise the degree of compatibility of expert opinions. If the number of experts is greater than 2, the level of compatibility of the experts in the group is determined by the Kendall concordance factor W. Three experts are asked to evaluate the significance of the criterion from 0.01 to 1 , the sum of the weight values of the proposed criteria must not be greater than 1 . While measuring the coefficient of concordance $W$, first of all, it is necessary to perform the ranking of expert evaluations, which is performed by assigning the bestevaluated criterion to the first rank, the second weighting to the second rank, etc. 
Table 4. Results on the multi-criteria valuation of reputational factors (source: prepared by the authors)

\begin{tabular}{|c|c|c|c|c|c|c|c|c|c|}
\hline & \multirow{2}{*}{$\begin{array}{l}\text { SAW } \\
\text { method } \\
\text { when } \\
\text { weights } \\
\text { equal }\end{array}$} & \multicolumn{3}{|c|}{$\begin{array}{l}\text { SAW according to the expert } \\
\text { valuations }\end{array}$} & \multirow{2}{*}{$\begin{array}{l}\text { Geometric } \\
\text { mean } \\
\text { method }\end{array}$} & \multirow{2}{*}{$\begin{array}{l}\text { COPRAS } \\
\text { method when } \\
\text { weights } \\
\text { equal }\end{array}$} & \multicolumn{3}{|c|}{$\begin{array}{l}\text { COPRAS according to the expert } \\
\text { valuations }\end{array}$} \\
\hline & & 1 expert & 2 expert & 3 expert & & & 1 expert & 2 expert & 3 expert \\
\hline Year & $\begin{array}{l}S_{j} \text { coeffi- } \\
\text { cient }\end{array}$ & $\begin{array}{l}\mathrm{S}_{\mathrm{j}} \text { coeffi- } \\
\text { cient }\end{array}$ & $\begin{array}{c}\mathrm{S}_{\mathrm{j}} \text { coeffi- } \\
\text { cient }\end{array}$ & $\begin{array}{c}\mathrm{S}_{\mathrm{j}} \text { coeffi- } \\
\text { cient }\end{array}$ & $\mathrm{S}$ value & $\begin{array}{c}\text { Significance } \\
\text { of Alternative } \\
\text { (Q) }\end{array}$ & $\begin{array}{c}\text { Significance } \\
\text { of Alternative } \\
\text { (Q) }\end{array}$ & $\begin{array}{c}\text { Significance } \\
\text { of Alternative } \\
\text { (Q) }\end{array}$ & $\begin{array}{c}\text { Significance } \\
\text { of Alternative } \\
(\mathrm{Q})\end{array}$ \\
\hline 2014 & 0.1972790 & 0.20451 & 0.20257 & 0.20116 & 0.1874574 & 0.1974083 & 0.2046016 & 0.2027576 & 0.2012907 \\
\hline 2015 & 0.1908123 & 0.19971 & 0.19008 & 0.18806 & 0.1835672 & 0.1918425 & 0.200468 & 0.1916125 & 0.189349 \\
\hline 2016 & 0.1967414 & 0.19370 & 0.18911 & 0.19390 & 0.1862251 & 0.1962699 & 0.193397 & 0.1884314 & 0.1934445 \\
\hline 2017 & 0.190780 & 0.18748 & 0.17904 & 0.18293 & 0.1839899 & 0.1903750 & 0.1871938 & 0.1784447 & 0.1824540 \\
\hline 2018 & 0.224386 & 0.2145 & 0.23918 & 0.23392 & 0.2135625 & 0.2245608 & 0.2146791 & 0.2394315 & 0.2340506 \\
\hline
\end{tabular}

Table 5 includes the ranks assigned to each of the factors by experts as well as the components of the formulas needed to obtain the Kendall value of the concordance. According to the assigned ranks, it can be seen that the 1st expert points out the significance of the "Global 100 Most Sustainable Corporations" and "Counterparty Risk Assessment" as equally highest among all of the factors. According to the 2nd expert, the most important factor while assessing the reputation is the bank's position in "Global 100 Most Sustainable Corporations" rating as well. While the 3rd expert believes that the bank's position in "Brand Finance Global Banking 100" ratings is the most valuable factor to assess. As for the least important factors, all of the experts had chosen the factor of social responsibility ranking in terms of environmental impact. The 18th rank is assigned to social responsibility rating in terms of the social impact by the 2 nd expert and the short-term (commercial papers issuance) obligations rating by the 1st and 3rd experts.

Table 5. Systematisation of data needed for the coefficient of concordance measurement (source: prepared by the authors)

\begin{tabular}{|l|c|c|c|c|c|c|}
\hline \multirow{2}{*}{\multicolumn{1}{|c|}{ Criteria }} & \multicolumn{2}{c|}{$\begin{array}{c}\text { Expert valuation } \\
\text { (ranking) }\end{array}$} & \multirow{2}{*}{$\mathrm{R}_{\mathrm{i}}$} & \multirow{2}{*}{$\mathrm{S}_{\mathrm{i}}$} & \multirow{2}{*}{$\mathrm{S}_{\mathrm{i}}^{2}$} \\
\cline { 2 - 6 } & $\mathrm{I}$ & $\mathrm{II}$ & $\mathrm{III}$ & & & \\
\hline Ratings: Brand Finance Global Banking 500 (100) & 3 & 2 & 1 & 6 & -23.315789 & 543.62604 \\
\hline Ratings: Global 100 Most Sustainable Corporations & 1.5 & 1 & 4 & 6.5 & -22.815789 & 520.56025 \\
\hline Ratings: Most Valuable Nordic Brands Top 50 & 5.5 & 3 & 2 & 10.5 & -18.815789 & 354.03393 \\
\hline Ratings: Green Ranking Global Top 100 & 4 & 4 & 3 & 11 & -18.315789 & 335.46814 \\
\hline $\begin{array}{l}\text { Development in the number of job ads over time } \\
\text { Denmark }\end{array}$ & 14 & 16 & 16 & 46 & 16.684211 & 278.36288 \\
\hline Social responsibility: Environment & 19 & 19 & 19 & 43 & 13.684211 & 187.25762 \\
\hline Social responsibility: Social & 16 & 18 & 10 & 44 & 14.684211 & 215.62604 \\
\hline Social responsibility: Governance & 17 & 17 & 11 & 45 & 15.684211 & 245.99446 \\
\hline Income statement: Operating expenses, DKK & 5.5 & 7 & 5 & 20 & -9.3157895 & 86.783934 \\
\hline Number of employees: analysed bank & 11 & 8 & 6 & 24 & -5.3157895 & 28.257618 \\
\hline Number of employees: competitor bank I & 8 & 6 & 8 & 21 & -8.3157895 & 69.152355 \\
\hline Number of employees: competitor bank II & 7 & 5 & 7 & 18 & -11.315789 & 128.04709 \\
\hline Moody's rating: Issuer Outlook (positive/negative) & 15 & 14.5 & 17 & 37 & 7.6842105 & 59.047091 \\
\hline $\begin{array}{l}\text { Moody's rating: Class History - Counterparty Risk } \\
\text { Assessment }\end{array}$ & 1.5 & 11 & 9 & 31.5 & 2.1842105 & 4.7707756 \\
\hline Moody's rating: Issuer Rating & 12 & 10 & 12 & 33 & 3.6842105 & 13.573407 \\
\hline Moody's rating: Commercial Paper & 10 & 12 & 14.5 & 38.5 & 9.1842105 & 84.349723 \\
\hline Moody's rating: Short Term value & 18 & 14.5 & 18 & 50.5 & 21.184211 & 448.77078 \\
\hline Moody's rating: Baseline Credit Assessment & 9 & 9 & 14.5 & 32.5 & 3.1842105 & 10.139197 \\
\hline Moody's rating: Bank Deposits Frequency & 13 & 13 & 13 & 39 & 9.6842105 & 93.783934 \\
\hline
\end{tabular}

It can be seen that there is additional data required for calculations of the Kendall concordance factor $W-R_{i}, S_{i}$, $S_{i}^{2} . R_{i}$ is the sum of the rankings of each criterion required for calculation of the $S_{i}$ indicator. Meanwhile, $S_{i}$ is the difference between the sum of the criteria rank $R_{i}$ and the average $R$ of all criteria rankings. The sum of all $S_{i}^{2}$ is used to calculate the concordance coefficient $W$. With the calculated $R_{i}$, the average of all factors' rankings that determine the reputation level: $R=29.316$. Having the calculated $S_{i}$ and $S_{i}^{2}$, the sum $S$ of $S_{i}^{2}$ measured for each factor $=3707.6$. The calculated $W$ value is equal to 0.72 . The resulting value indicates that $W$ is close to 1 , therefore, it can be said that expert opinions are sufficiently harmonised. It means that the study involving the estimates proposed by experts can 
be continued. Taking into account the valuation of the experts while assessing the SAW method for multi-criteria assessment, it can be noted that the $1^{\text {st }}$ place is taken by 2018 -year's activity (Table 6). The most significant effect on the analysed bank by the chosen reputational factors is measured at the level of 0.2145 by the $1^{\text {st }}$ expert, 0.23918 by the $2^{\text {nd }}$ expert and 0.23392 by the $3^{\text {rd }}$ expert - which are the highest among other valuation years. Highest $S_{j}$ coefficients are assigned to the 2014 year of the bank's activity as well -0.20451 by the $1^{\text {st }}$ expert, 0.2025 by the $2^{\text {nd }}$ expert and 0.2012 by the $3^{\text {rd }}$ expert.

The least affected year according to SAW method in terms of weights based on the experts' opinion is 2017 which means that reputational risk occurrence during this year has been the lowest in terms of bank's activity.

When using the geometric average method, it is important to use normalised data to calculate the significant coefficients. It is worth to note that the use of weights is not relevant for this method; therefore, the effect of equal or expert weights on results is not emphasised on the basis of the geometric mean method.

The geometric average method gives an insight that the mostly affected year by the reputation is 2018 with the significance value of 0,2135 . While the year which in terms of activity has not been affected by the reputational events was 2015 - the measured $\Pi_{j}$ value reaches the level of 0.1835 .

Table 6. Evaluating the years of company's activity based on reputational factors (source: prepared by the authors)

\begin{tabular}{|c|c|c|c|c|c|c|c|c|c|}
\hline \multirow{2}{*}{ Place } & \multirow{2}{*}{$\begin{array}{c}\text { SAW } \\
\text { method } \\
\text { when } \\
\text { weights } \\
\text { equal }\end{array}$} & \multicolumn{3}{|c|}{$\begin{array}{l}\text { SAW according to the expert } \\
\text { valuations }\end{array}$} & \multirow{2}{*}{$\begin{array}{c}\text { Geometric } \\
\text { mean } \\
\text { method }\end{array}$} & \multirow{2}{*}{$\begin{array}{l}\text { COPRAS } \\
\text { method when } \\
\text { weights equal }\end{array}$} & \multicolumn{3}{|c|}{$\begin{array}{l}\text { COPRAS according to the } \\
\text { expert valuations }\end{array}$} \\
\hline & & I expert & 2 expert & 3 expert & & & $\begin{array}{c}\text { I } \\
\text { expert }\end{array}$ & $\begin{array}{c}2 \\
\text { expert }\end{array}$ & $\begin{array}{c}3 \\
\text { expert }\end{array}$ \\
\hline I & 2018 & 2018 & 2018 & 2018 & 2018 & 2018 & 2018 & 2018 & 2018 \\
\hline II & 2014 & 2014 & 2014 & 2014 & 2014 & 2014 & 2014 & 2014 & 2014 \\
\hline III & 2016 & 2015 & 2015 & 2016 & 2016 & 2016 & 2015 & 2015 & 2016 \\
\hline IV & 2017 & 2016 & 2016 & 2015 & 2017 & 2015 & 2016 & 2016 & 2015 \\
\hline $\mathrm{V}$ & 2015 & 2017 & 2017 & 2017 & 2015 & 2017 & 2017 & 2017 & 2017 \\
\hline
\end{tabular}

In order to ensure the accuracy of the received data, it is important to perform a reputation impact analysis by COPRAS method and compare the results obtained with SAW and geometric mean methods - as the CORAS method provides a more accurate estimation of criteria significance. Following the same logic as while applying the SAW method, first, the study is carried out on the assumption that each of the investigated factors is equally important and significant. At this stage, in order to continue the COPRAS study, it is essential to find out which of the determinants of reputation may have both a positive and a negative impact on the company's activity. In this way, $Q_{j}$ indexes for reducing and increasing relative significance are determined. Analysing available factors and their potential impact on reputation, reducing indices are applied to the employees in competing banks. Accordingly, increasing indices are attributed to all other 17 reputational factors left. Further, with normalised data and set reputation reducing and increasing indices, it is necessary to measure the amounts of maximising and minimising normalised scores. Having the sums of normalised scores carrying certain effect, the $Q_{j}$ criteria can be calculated. Applying the COPRAS method with equal weights of 0.053 out of 1 , the mostly affected year within the reputation is 2018 with the point of 0.2245 (which is the highest value for 2018 compared to the results proposed by other methods). The lowest significance level ( 0.1903 ) confirms the results provided by the SAW method based on experts' evaluations - the year when the company avoided the reputational impact was 2017. When relying on experts' evaluations, it can be seen, that performed analysis suggests the same significance levels, which are attributable to the company's year activity by all of the experts - the mostly affected years are 2018 and 2014, while the least - 2016 and 2017 . The significance measurement for 2018 year fluctuates from 0.214 to 0.239 , while for the 2017 - from 0.178 to 0.187 .

In all of the cases proposed by different methodologies, the reputational impact has been at the largest scale during 2018 and 2014 years. The calmest years for the analysed financial company in terms of the reputational impact have been the 2015 and 2017 - as the rankings for the mentioned years differ in accordance with the methodology used in the multi-criteria assessment. Accorded rankings for the company's yearly activity are mainly influenced by the ranks the analysed bank has placed in the records of "Brand Finance Global Banking 100", "Global 100 Most Sustainable Corporations", "Most Valuable Nordic Brands Top 50", and "Green Ranking Global Top 100". The operating expenses, numbers of employees in competitors' banks as well as debt instruments and securities assessment provided by Moody's also influences the position of a bank. The impact of other factors has also been taken into account, however, lowering the scale of that on the company's reputational image. 


\section{Conclusions}

Malfunctioned risk management can lead to a loss of organisation reputation. As reputation is associated with consequences of non-financial risk, reputational risk is assigned to the operational risk group. The reputation of an organisation can be associated with a social identity, which is particularly important in the positioning strategy because of its significant influence on the choice of the customer's financial services. It can be concluded that reputational risk is the possibility to have an impact on performance results through certain events, which increases the likelihood of achieving the organisation's goals. Reputation dimensions, such as financial performance, vision and leadership, goods and services, work environment, social responsibility, and emotional attractiveness, can help to assess organisational reputation. In order to measure the reputational impact precisely, the root cause of occurred risk should be investigated in the scope of reputation dimensions. As far as construct based approach for the company's assessment is not possible relying solely on an individual basis, therefore, the organisation's reputation is the public's comprehensive assessment over time. Mostly impacted period of analysed bank's activity is selected by conducting a multi-criteria analysis. To put into practice multi-criteria methods, in view of bank activity the data regarding the reputational criteria is collected during the interview process with three selected experts. The potential interviewers met the requirements related to experience in risk management, customer interaction, and financial operations processes. As a result, the group of two team leads and one expert (employee) set the reputational data set with the relative importance levels. The reputational factors proposed by the interviewers were evaluated conducting a multi-criteria analysis in terms of the most affected period of the company's activity. According to the expert opinion, the factors which outline the reputational extent of the company are the financial, corporate sustainability, branding ratings of the bank, the position of the debt and equity instruments as well as the workforce of the market parties. The SAW, COPRAS and geometric average methodologies have shown that the results of the analysed bank were mostly affected in 2014 and 2018 years. Analysing the periods when the bank has not experienced a significant impact on the reputation, the least affected activity is identified in 2015 and 2017 years.

The degree of reputation and the impact of repercussions on the organisation's performance can be further assessed through financial analysis. The financial analysis provides better definition of the phenomena and processes in the company. Although the repercussions of reputational risk can be difficult to measure, financial analysis results can be used successfully in reputation risk management solutions. The results of financial performance analysis may not only testify to the loss that has already occurred, but also predicts what the future prospects of the organisation are for the event of reputational risk. In order to carry out the performance analysis for a particular company, it is appropriate to rely on the balance sheet and profit-loss statements along with a financial analysis of relative indicators.

\section{References}

Azar, A., \& Mostafaee Dolatabad, K. (2019). A method for modelling operational risk with fuzzy cognitive maps and Bayesian belief networks. Expert Systems with Applications, 115, 607-617. https://doi.org/10.1016/j.eswa.2018.08.043

Barakat, A., Ashby, S., Fenn, P., \& Bryce, C. (2019). Operational risk and reputation in financial Institutions: Does media tone make a difference? Journal of Banking and Finance, 98, 1-24. https://doi.org/10.1016/j.jbankfin.2018.10.007

Basel Committee on Banking Supervision. (2003). The joint forum. Operational risk transfer across financial sectors.

Basel Committee on Banking Supervision. (2006). International convergence of capital measurement and capital standards. A revised framework comprehensive version.

Basel Committee on Banking Supervision. (2009). Guidelines for computing capital for incremental risk in the trading book.

Bergh, D. D., Ketchen, D. J., Boyd, B. K., \& Bergh, J. (2010). New frontiers of the reputation-performance relationship: Insights from multiple theories. Journal of Management, 36(3), 620-632. https://doi.org/10.1177/0149206309355320

Braga, D. D. E. S., Niemann, M., \& Hellingrath, B. (2018). Survey on Computational Trust and Reputation Models. ACM Computing Surveys (CSUR), 51(5). https://doi.org/10.1145/3236008

Bromiley, P., McShane, M., Nair, A., \& Rustambekov, E. (2015). Enterprise risk management: review, critique, and research directions. Long Range Planning, 48(4), 265-276. https://doi.org/10.1016/j.lrp.2014.07.005

Carroll Craig, E. (2015). The handbook of communication and corporate reputation. West Sussex: John Wiley and Sons.

Černikovaitè, M. E. (2018). Prekių ženklų krizės ir jų komunikacijos strategijos. Informacijos Mokslai, 81, 133-145. https://doi.org/10.15388/Im.2018.0.11945

De Luca, P. (2017). The company fundamental analysis and the default risk ratio. International Journal of Business and Management, 12(10), 79. https://doi.org/10.5539/ijbm.v12n10p79 
Fombrun, C. J., Ponzi, L. J., \& Newburry, W. (2015). Stakeholder tracking and analysis: The RepTrak® System for measuring corporate reputation. Corporate Reputation Review, 18(1), 3-24. https://doi.org/10.1057/crr.2014.21

Ginevičius, R., \& Podvezko, V. (2008). Daugiakriterinio vertinimo būdo suderinamumas. Verslas: Teorija ir Praktika 9(1). https://doi.org/10.3846/1648-0627.2008.9.73-80

González Sánchez, M., \& Morales de Vega, M. E. (2018). Corporate reputation and firms' performance: Evidence from Spain. Corporate Social Responsibility and Environmental Management, 25(6), 1231-1245. https://doi.org/10.1002/csr.1634

Hedgecoe, A. (2016). Reputational risk, academic freedom and research ethics review. Sociology, 50(3), $486-501$. https://doi.org/10.1177/0038038515590756

Lange, D., Lee, P. M., \& Dai, Y. (2011). Organizational reputation: A review. Journal of Management, 37(1), 153184. https://doi.org/10.1177/0149206310390963

Maden, C., Arıkan, E., Telci, E. E., \& Kantur, D. (2012). Linking corporate social responsibility to corporate reputation: a study on understanding behavioral consequences. Procedia - Social and Behavioral Sciences, 58, 655-664. https://doi.org/10.1016/j.sbspro.2012.09.1043

Matuleviciene, M., \& Stravinskiene, J. (2015). The importance of stakeholders for corporate reputation. Engineering Economics, 26(1), 75-83. https://doi.org/10.5755/j01.ee.26.1.6921

Miles, M., Huberman, M., \& Saldana, J. (2018). Qualitative data analysis. A methods sourcebook (4rth Ed.). SAGE Publications, Inc.

Nguyen, N., \& LeBlanc, G. (2018). The combined effects of service offering and service employees on the perceived corporate reputation. Athens Journal of Business \& Economics, 4(2), 129-146. https://doi.org/10.30958/ajbe.4.2.1

Petrokaite, K., \& Stravinskienè, J. (2014). Corporate reputation management decisions: customer's perspective. Engineering Economics, 24(5). https://doi.org/10.5755/j01.ee.24.5.3920

Tuan, L. T. (2016). From cultural intelligence to supply chain performance. International Journal of Logistics Management, 27(1), 95-121. https://doi.org/10.1108/IJLM-01-2014-0009

Xu, C., Zheng, C., Wang, D., Ji, J., \& Wang, N. (2019). Double correlation model for operational risk: Evidence from Chinese commercial banks. Physica A: Statistical Mechanics and Its Applications, 516, $327-339$. https://doi.org/10.1016/j.physa.2018.10.031

Yang, S. O., Hsu, C., Sarker, S., \& Lee, A. S. (2017). Enabling effective operational risk management in a financial institution: an action research study. Journal of Management Information Systems, 34(3), 727-753. https://doi.org/10.1080/07421222.2017.1373006

Yazdani, M., Alidoosti, A., \& Zavadskas, E. K. (2015). Risk analysis of critical infrastructures using fuzzy copras. Economic Research-Ekonomska Istraživanja, 24(4), 27-40. https://doi.org/10.1080/1331677X.2011.11517478 